\title{
A u-shaped backward masking function in vision: A partial replication of the Weisstein and Haber study with two ring sizes
}

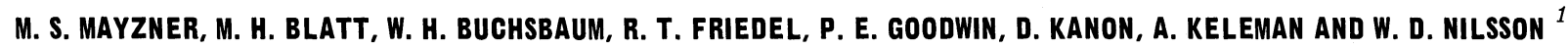

NEW YORK UNIVERSITY

\begin{abstract}
Abstraet
A partial replication of the visual masking study by Weisstein \& Haber (1965) was performed incorporating the additional variable of masking ring size in order to investigate the discrepancy between findings of that study and the study by Eriksen \& Collins (1964). Errors in discriminating the capital letters 0 and $\mathrm{D}$ in a forcedchoice design were measured with 4 Ss when the exposure of either letter was accompanied or followed by either a masking ring of a stroke width equal to that of the letter or five times as large as the stroke width of the letter. The delays between the offset of the letter and the onset of the masking ring were concurrent, 0 , $20,40,60$, and $80 \mathrm{msec}$. Recognition was a u-shaped function of the delay for both ring sizes; however, the number of errors for the two ring sizes differed significantly, with the smaller ring having more overall errors. Therefore, the results approximated those of Weisstein \& Haber, and indicated that masking ring size is an important variable in visual masking studies, although this variable alone did not produce the discrepancy that is found between Weisstein \& Haber and Eriksen \& Collins. Problem
\end{abstract}

Certain visual masking studies have indicated that visual backward masking follows u-shaped functions (Kolers, 1962; Weisstein \& Haber, 1965). Other studies have indicated that visual masking follows a decreasing monotonic function with respect to delay in either direction between the stimulus and ring (Eriksen \& Collins, 1964; Eriksen \& Lappin, 1964). Still another study, which partially replicated Averbach \& Coriell (1961), found a function with zero slope from 50 to 150 msec. (Mayzner et al, 1964).

Eriksen has stated that the previously obtained ushaped functions were artifactual, since it was possible that the Ss used different means of detection with different delays because of the lack of a concurrent condition and a forced-choice situation, and the type of indicator used. The purpose of the study by Weisstein \& Haber was to show that the u-shaped functions could be obtained while meeting Eriksen's objections.

It is difficult to understand why maximum masking occurred at the concurrent condition in the study by Eriksen \& Collins, and also why the Eriksen \& Collins and Weisstein \& Haber studies should have such differently shaped functions. The purpose of the present study is to partially replicate the study of Weisstein \& Haber and to investigate further the discrepancy between the shapes of the functions in these two studies. Since one of the major differences between the two studies seemed to be the stroke width of the masking ring, both large and small masking ring stroke widths were used in the present study.

\section{Method}

Apparatus and materials

The stimuli, letters "O" and 'D"', were presented in a three-field tachistoscope (Scientific Prototype, Model GA), following Weisstein \& Haber (1965). A fixation point which subtended an angle of $0.1^{\circ}$ was presented before each stimulus. The angular distances between the fixation point and the center of a letter was $0.61^{\circ}$ for the letters appearing in the two middle positions, and $1.73^{\circ}$ for those in the two outside positions. The letters were exposed for $20 \mathrm{msec}$. in one field, and the rings for $50 \mathrm{msec}$. in another field, after the presentation of the fixation point in the third field. Procedure and subjects

The delay interval, position of the stimuli in one of four positions, and the two letters were presented in random order. The two masking ring sizes were presented in counterbalanced order, i. e., 72 trials of $0.05^{\circ}, 72$ trials of $0.25^{\circ}, 72$ trials of $0.25^{\circ}$, and 72 trials of $0.05^{\circ}$. There were 24 trials for each of the six delay intervals (C, 0, 20, 40,60, and $80 \mathrm{msec}$.) for each masking ring size; and therefore, 288 trials for each $S$. At the beginning of each trial the $S$ was given a ready signal to which he would respond when fixated. The trials were administered during six three-hour class sessions over a period of seven weeks. $S$ was required to respond either "O" or "D". No "do not know" response was permitted. The four Ss (three males and one female) were students in a graduate Research Methods course. A comparison of the stimuli, apparati, and procedures employed in the studies by Eriksen \& Collins (1964) and Weisstein \& Haber (1965) and the present study are presented in Table 1.

\section{Results and Discussion}

Since the present study was concerned with partially replicating Weisstein \& Haber (1965) and relating these results to Eriksen \& Collins (1964), Fig. 1 presents the percentage of errors for various delay intervals for the three studies. The results presented in Fig. 1 show very clear $u$-shaped functions for both the $.05^{\circ}$ and $.25^{\circ}$ masking ring conditions of the present study, and appear quite similar to the function found by Weisstein \& Haber, 
TABLE I. COMPARISON OF STIMULI, APPARATI, AND PROCEDURES USED IN THE THREE STUDIES

\begin{tabular}{|c|c|c|c|}
\hline & $\begin{array}{l}\text { Eriksen } \\
\& \text { Collins }\end{array}$ & $\begin{array}{l}\text { Weisstein } \\
\& \text { Haber }\end{array}$ & $\begin{array}{l}\text { Present } \\
\text { Study }\end{array}$ \\
\hline Letters & $\mathrm{A}, \mathrm{T}, \mathrm{U}$ & O, D & $O, D$ \\
\hline Letter height & $.20^{\circ}$ & $.62^{\circ}$ & $.60^{\circ}$ \\
\hline Letter width & $.20^{\circ}$ & $.30^{\circ}$ & $.40^{\circ}$ \\
\hline $\begin{array}{l}\text { Letter } \\
\text { stroke width }\end{array}$ & does not state & $.08^{\circ}$ & $.05^{\circ}$ \\
\hline $\begin{array}{l}\text { Masking ring } \\
\text { inner diameter }\end{array}$ & $.30^{\circ}$ & $.61^{\circ}$ & $.76^{\circ}$ \\
\hline $\begin{array}{l}\text { Masking ring } \\
\text { stroke width }\end{array}$ & $.37^{\circ}$ & $.05^{\circ}$ & $\begin{array}{l}.05^{\circ} \\
.25^{\circ}\end{array}$ \\
\hline $\begin{array}{l}\text { Exposure of } \\
\text { Letter }\end{array}$ & $\begin{array}{l}\text { Duration neces- } \\
\text { sary for } 70 \% \\
\text { accuracy for } \\
\text { letters without } \\
\text { rings. }\end{array}$ & $20 \mathrm{msec}$. & $20 \mathrm{msec}$. \\
\hline \multicolumn{4}{|l|}{ Exposure of } \\
\hline \multirow{2}{*}{$\begin{array}{l}\text { Fixation point: } \\
\text { size, type, } \\
\text { duration, } \\
\text { brightness }\end{array}$} & 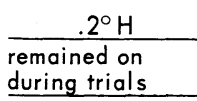 & $\frac{\text { less than } 2^{\prime}}{\text { does not state }}$ & $\begin{array}{l}.1^{\circ} \text { dot } \\
\begin{array}{l}\text { did not remain } \\
\text { during trials }\end{array}\end{array}$ \\
\hline & $\begin{array}{l}.572 \text { apparent } \\
\mathrm{ft} \text { candles }\end{array}$ & does not state & $\begin{array}{l}\text { maximum setting } \\
\text { of } 10\end{array}$ \\
\hline $\begin{array}{l}\text { Luminance of } \\
\text { test field }\end{array}$ & $\begin{array}{l}.200+.572 \\
\text { apparent } \\
\mathrm{ft} \text { candles }\end{array}$ & does not state & $\begin{array}{l}\text { maximum setting } \\
\text { of } 10\end{array}$ \\
\hline Tachistoscope & $\begin{array}{l}\text { 3-field, by } \\
\text { Merle Ridgely } \\
\text { \& Co. }\end{array}$ & $\begin{array}{l}\text { Scientific } \\
\text { Prototype, } \\
\text { Model D }\end{array}$ & $\begin{array}{l}\text { Scientific } \\
\text { Prototype, } \\
\text { Model, GA }\end{array}$ \\
\hline $\begin{array}{c}\text { Number of } \\
\text { subjects }\end{array}$ & $\begin{array}{l}10 \text { for } C, O, \\
\& 250 ; 5 \text { for } \\
1025,50,68, \\
10 b, \& 130\end{array}$ & $\begin{array}{l}4 \text { (2 for } \\
0 \text { msec. })\end{array}$ & 4 \\
\hline $\begin{array}{l}\text { Trials for } \\
\text { each subject }\end{array}$ & $\begin{array}{l}45 \text { for each } \\
\text { delay for ring } \\
\text { present }\end{array}$ & $\begin{array}{l}64 \text { for each } \\
\text { delay interval }\end{array}$ & $\begin{array}{l}24 \text { for each } \\
\text { delay for each } \\
\text { of } 2 \text { rings }\end{array}$ \\
\hline
\end{tabular}

but are in marked contrast to the function obtained by Eriksen \& Collins. Errors in recognition were analyzed by analysis of variance and showed ring size was significant at beyond the .05 level, delay interval was significant at beyond the .01 level, while the interaction of ring size and delay interval was insignificant. The .050 ring size showed significantly more overall errors than the $.25^{\circ}$ ring size; also, errors by position showed maximum errors occurred in position one followed by positions two, four and three in that order, and there were twice as many errors for the letter " $O$ " than for the letter " $D$ ".

It had been anticipated that the $.25^{\circ}$ masking ring condition would have more approximated the function obtained by Eriksen \& Collins, who also employed a "thick" masking ring. Since this expectation was not confirmed, it would appear that thickness of masking ring while affecting percentage errors does not, at least

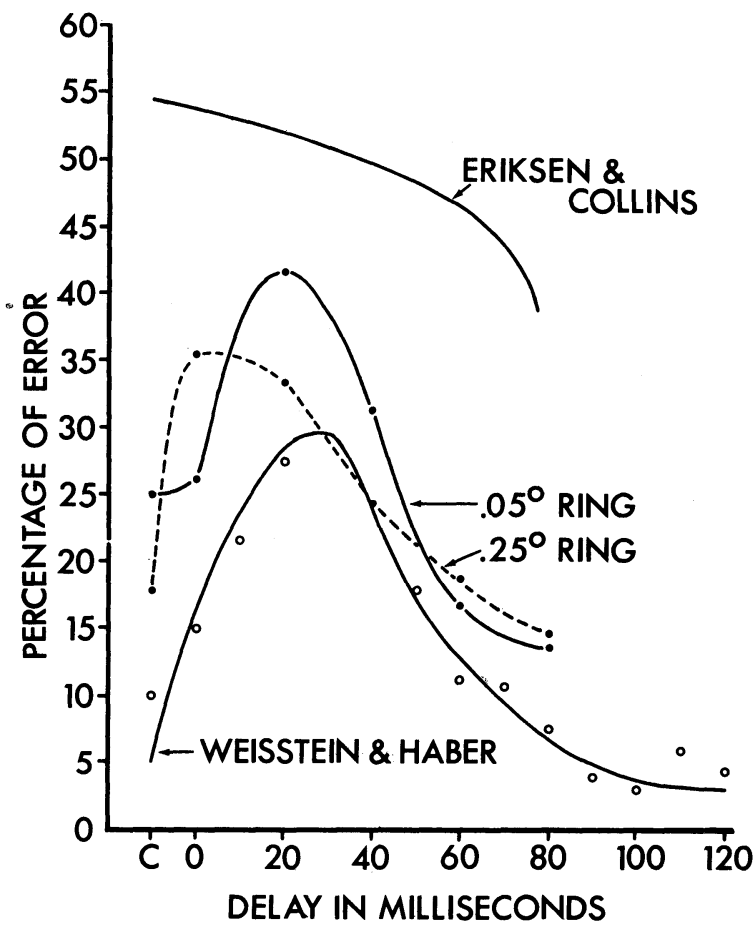

Fig. 1. Comparison of masking errors from present study, Eriksen and Collins, and Weisstein and Haber.

for the values examined, chage the $u$-shaped character of the function. It is of some interest though that thickness of masking ring does affect percentage of errors and apparently shifts the point at which the function peaks to the left; a finding which warrants further study. Examination of Table 1 shows, however, a number of differences which exist between all three studies, i. e., the present study and the studies of Eriksen \& Collins and Weisstein \& Haber. Parametric variation then of many of the factors listed in Table 1 will be required to firmly establish those conditions in visual masking under which a u-shaped function is obtained or a decreasing monotonic function.

\section{References}

Averbach, E., \& Coriell, A. S. Short-term memory in vision. Bell Sys. tech. J., 1961, 40, 309-328.

Eriksen, C. W., \& Collins, J. F. Backward masking in vision.. Psychon. Sci., 1964, 1, 101-102.

Eriksen, C. W., \& Lappin, J. S. Luminance summation-contrast reduction as a basis for certain forward and backward masking effects. Psychon. Sci., 1964, 1, 313-314.

Kolers, P. A. Intensity and contour effects in visual masking. Vis. Res., 1962, 2, 277-292.

Mayzner, M. S., Abrevaya, E. L., Frey, R. E., Kaufman, H. G., \& Schoenberg, K. M. Short-term memory in vision: A partial replication of the Averbach and Coriell study. Psychon. Sci., 1964, 1, 225-226.

Weisstein, Naomi, \& Haber, R. N. A u-shaped backward function in vision. Psychon. Sci., 1965, 2, 75-76:

\section{Note}

1. This study was performed by the seven junior authors as part of a class project in a graduate Research Methods course given by the senior author. 